\title{
THE QUALITY PARAMETERS, TOTAL FLAVONOIDS DETERMINATION AND ANTIOXIDANT ACTIVITY COMPOUND OF ANDALIMAN FRUIT ANDALIMAN FRUIT (ZANTHOXYLUM ACANTHOPODIUM DC.) EXTRACT
}

\author{
YUNAHARA FARIDA ${ }^{1}$, WIDI AZELA ${ }^{1}$, MEGA ELOK LESTARI'1, DIAH KARTIKA PRATAMI ${ }^{1}$
}

1Faculty of Pharmacy, Pancasila University, Jakarta 12640, Indonesia

*Email: yunahara.faridah@univpancasila.ac.id

Received: 07 Sep 2020, Revised and Accepted: 08 Oct 2020

\section{ABSTRACT}

Objective: The aim of this study was to investigate the chemical compound of the antioxidant activity of the extract from andaliman fruit (Zanthoxylum acanthopodium DC.) and the quality parameters and the total flavonoid determination of the highest antioxidant activity.

Methods: The andaliman fruits were extracted using a solvent such as n-hexane, ethyl acetate and 70\% ethanol obtained extracts, follow the antioxidant activity using the 2,2-diphenyl-1-picrylhydrazyl (DPPH) method. The quality parameters and total flavonoid determination were performed from highest antioxidant activity. Fractionated was done using vacuum liquid chromatography (VLC) with the mobile phase chloroformmethanol (9:1 1:9). Purification with Thin Layer Chromatography (TLC) preparative, identification using UV-spectrophotometry, FTIR, Gas chromatography Mass Spectrometry (GCMS) analysis.

Results: The $70 \%$ of ethanol has the highest antioxidant activity with $\mathrm{IC}_{50}$ value $84.11 \pm 0.47$ ppm; the quality parameters in this study meet the quality requirements, both specific and nonspecific parameters. Total flavonoid content of the $70 \%$ ethanol extract was $2.37 \pm 0.02 \%$. The results of the GCMS studies showed the presence of 1,2-benzenedicarboxylic acid, mono (2-ethylhexyl) ester; squalene, methyl palmitate, methyl isopalmitate, n-tetracosanol-1 and 4-isopropyl chalcone.

Conclusion: The results indicate that the 70\% ethanol extracts of andaliman fruits contains 1,2-benzenedicarboxylic acid, mono (2-ethylhexyl) ester; squalene, methyl palmitate, methyl isopalmitate, n-tetracosanol-1 and 4-isopropyl chalcone have antioxidant activity with IC 50 value 51.35 ppm.

Keywords: Andaliman Fruit (Zanthoxylum acanthopodium DC.), Antioxidant, DPPH, Quality parameters, Total flavonoid

(C) 2021 The Authors. Published by Innovare Academic Sciences PvtLtd. This is an open access article under the CC BYlicense (http://creativecommons.org/licenses/by/4.0/) DOI: http://dx.doi.org/10.22159/ijap.2021.v13s2.07 Journal homepage: https://innovareacademics.in/journals/index.php/ijap

\section{INTRODUCTION}

Natural antioxidants have various pharmacological effects such as antiinflammatory, anticancer, antibacterial and antiviral activities [1, 2]. One of the plants in Indonesia that is widely used by the Batak tribe as a cooking spice that can also be used as medicine is the fruit of Andaliman. The part of plants often used are leaves and fruits. The fruit can be used to treat digestion, asthma and bronchitis, relieve pain, heart disease, mouth, teeth and throat disease, as well as to treat diarrhea [3], as antimycobacterial against Mycobacterium smegmatis [4]

Andaliman fruit (Zanthoxylum acanthopodium DC.), family Rutaceae is known to contain phytochemical compounds such as flavonoids, alkaloids, steroids and saponins [5]. Flavonoids in andaliman fruit are thought to play an active role as antioxidants [6]. Flavonoid is one of the most widespread and important secondary metabolites that possess various biological activities i.e. they are good scavengers of the most oxidizing molecules, including various free radicals [7].

The results of previous studies conducted by Kristanti RE, the antioxidant activity of andaliman fruit methanol extract using the DPPH method, obtained values of $26.39 \mu \mathrm{g} / \mathrm{ml}$ and n-butanol extracts had values of $53.51 \mu \mathrm{g} / \mathrm{ml}$ [8]. The chemical compounds identified in fruits of andaliman's essential oil with some major compounds such as geranyl acetate, citronella, $\beta$-citronelol, nerol, limonene, geraniol, caryophyllene, citronellyl acetate, and $\alpha$-pinene [9].

Therefore, this study was conducted to identify chemical compounds, the quality parameter dan total flavonoid content that has antioxidant activity from the active extract of Andaliman fruit.

\section{MATERIALS AND METHODS}

\section{Samples}

Andaliman fruit (Zanthoxylum acanthopodium DC were obtained from Medan, North Sumatra. Andaliman has the taxonomic plant identification number 207/IPH.1.01/if.07/I/2018 at the Herbarium
Bogoriense, Botanical Division, Research Center for Biology, Indonesian Institute of Science (LIPI) Bogor, West Java, Indonesia.

\section{Chemicals and reagents}

All chemicals were obtained from commercial sources and were analytical grade. n-hexane, ethyl acetate; ethanol; magnesium powder (turnings powder, 98\%, reagent grade), hydrochloric acid (37\% analytical grade), amyl alcohol (99,8\%, analytical grade), chloroform, ether, Dragendorff's reagent, Mayer's reagent, Stiasny reagent, anhydrous acetic acid, sulfuric acid, nitric acid, amonia 30\%, gelatin solution, iron (III) chloride, sodium acetate, acetonitrile, magnesium sulfate 25\%, Potato Dextrose Agar (PDA), Nutrient Agar (NA), phosphate buffer $0.1 \mathrm{M} \mathrm{pH} \mathrm{7.0,} \mathrm{hexamethylentetramine,}$ acetone, ascorbic acid, DPPH; methanol, quercetine, sephadex LH20, silica gel60.

\section{Preparation extract}

The dried powdered of andaliman fruits were extracted with kinetic maceration by the following solvents with increasing polarity: nhexane, ethyl acetate and $70 \%$ ethanol. The extracts were filtered and dried in a rotary vacuum evaporator into the crude extract.

\section{Phytochemical screening}

Phytochemical screening test was conducted according to Farnsworth's and Harborne's method $[10,11]$ to identify compounds of samples such as alkaloids by Dragendorff's reagent/Mayer's reagent, flavonoids by the reduction test $(\mathrm{Mg}-\mathrm{HCl} /$ amylacohol), saponins by the foam formation test, tannins by the iron (III) chloride reagent, quinone by the $\mathrm{NaOH}$ reagent, steroids/triterpenoids by the Liebermann-Burchard's reagent, coumarins by the fluorescene test with ammonia and essential oil by the odor test.

\section{Antioxidant activity test}

Test for antioxidant activity of andaliman extract was using the stable DPPH. Five concentrations are made $75 ; 100 ; 125 ; 150$ ppm 
(ethyl acetate and $70 \%$ of ethanol extract) and 100; 200; 300; 400; $500 \mathrm{ppm}$ (n-hexane extract) then incubated at $37^{\circ} \mathrm{C}$ for $30 \mathrm{~min}$ The absorbance was recorded at $516.5 \mathrm{~nm}$ using UV-Visible spectrophotometer. The experiment was repeated for 3 times. Vitamin $\mathrm{C}$ was used as a standard control. $\mathrm{IC}_{50}$ values denote the concentration of the sample, which is required to scavenge $50 \%$ of DPPH free radicals $[12,13]$.

\section{Specific quality parameters determination}

The quality parameter was determined organoleptic, measurement of soluble compound content, ethanol-soluble compound content, and water-soluble compound content. Organoleptic test was analyzed the consistency, color, smell of the extract that visually observed. Watersoluble compound was determined by macerated $1 \mathrm{~g}$ extract in $20 \mathrm{ml}$ chloroform for $24 \mathrm{~h}$. Filter and evaporate $4 \mathrm{ml}$ of the filtrate to dryness, which has been preweighed, and heat the residue in an oven at $105^{\circ} \mathrm{C}$ until constant weight. Calculate the water-soluble compound. Ethanol soluble compound was determined by macerated $1 \mathrm{~g}$ extract in $20 \mathrm{ml}$ ethanol for $24 \mathrm{~h}$. Filter and evaporate $4 \mathrm{ml}$ of the filtrate to dryness, which has been preweighed, and heat the residue in an oven at $105^{\circ} \mathrm{C}$ until constant weight.

\section{Non-specific quality parameters determination}

The non-specific quality parameters determination has analyzed the loss on drying, water content, total ash content, acid insoluble ash content, water-soluble ash content, residual solvent content, heavy metal, and microbial contamination (Total Plate Number and Molds and Yeasts Number).

The loss on drying was determined by weighed about $1 \mathrm{~g}$ extract in the shallow weighing bottle, which has been heated at a temperature of $105{ }^{\circ} \mathrm{C}$ for $30 \mathrm{~min}$ and then dried at a temperature of determination to reach a constant weight. Residual solvent determined using gas-liquid chromatography with a flame ionization detector and a glass column $30 \mathrm{~cm} \times 0.32 \mathrm{~mm}$ stationary phase flowed TR-WAX with a particle size of 100-200 mesh and nitrogen as a carrier gas.

Water content was determined using Karl Fischer reactor. Total ash content was determined by weighed about 2 g extract and then put the extract in the silicate crucible, which has been heated at $450{ }^{\circ} \mathrm{C}$ until the weight is fixed and weighed. Calculate the ash content in comparison with the air-dried extract.

The acid-insoluble ash content was determined by boil the ash that had been obtained in the measurement of total ash content in $25 \mathrm{ml}$ hydrochloride acid for $5 \mathrm{~min}$. collect the acid-insoluble ash. Filter using an ash-free paper filter, wash with hot water and centrifuge the residue and paper filter under a temperature of $400-600{ }^{\circ} \mathrm{C}$ to produce a constant weight. Acid-insoluble ash content was determined in comparison with the air-dried extract.

Microbial contamination determination was analyzed the Total Plate Count (TPC) and Molds and Yeasts Count (MYC). The TPC was determined by the weighed amount of $1,0 \mathrm{~g}$ of extract carefully examined or measured, put into $10 \mathrm{ml}$ volumetric flask, add phosphate buffer $\mathrm{pH} 7,0$ up to $10 \mathrm{ml}$, mix. The mixture obtained form of a solution or clear liquids, continue the experiment by Total Plate Count. After the procedure above is done (a $10^{-1}$ dilution) and then pipette $1 \mathrm{ml}$ of the sample that is mixed put $9 \mathrm{ml}$ of phosphate buffer $\mathrm{pH} 7,2$. It is a $10^{-2}$ dilution. Subsequent dilutions were made to $10^{-6}$. From each dilution pipette $1 \mathrm{ml}$ in to a sterile petri dishandmade triplo. Into each petri dishpoured NA $15-20 \mathrm{ml}$ of seed medium $\left(45 \pm 1{ }^{\circ} \mathrm{C}\right)$ and then shaken and rotated until the suspension is spread evenly. Blanko made on the petri dish filled with $1 \mathrm{ml}$ of diluent and media in order. After the medium solidified, petri dishes were incubated at $35-37{ }^{\circ} \mathrm{C}$ for $24 \mathrm{~h}$ in the inverted position. The number of colonies that grew was observed and counted. The determination of molds and yeasts number procedure same with TPC method using Potato Dextrose Agar as media.

The analyzed of heavy metal contamination ( $\mathrm{Cd}$ and $\mathrm{Pb}$ ) by using Atomic Absorption Spectrophotometry method.

\section{Total flavonoid determination}

Aluminum chloride colorimetric method was used for total flavonoid content. Each plant extracts $\left(0.5 \mathrm{ml}\right.$ of $\left.1: 10 \mathrm{~g} \mathrm{ml}^{-1}\right)$ in methanol were separately mixed with $1.5 \mathrm{ml}$ of methanol, $0.1 \mathrm{ml}$ of $10 \%$ aluminum chloride, $0.1 \mathrm{ml}$ of $1 \mathrm{M}$ potassium acetate and $2.8 \mathrm{ml}$ of distilled water. It remained at room temperature for $30 \mathrm{~min}$; the absorbance of the reaction mixture was measured at $415 \mathrm{~nm}$ with UV/Visible spectrophotometer.

\section{Fractionation}

The active extract was separated on silica gel 60 using vacuum liquid chromatography (VLC) with a step gradient elution of the following composition chloroform: methanol solvent (90:10 10:90. All the fractions were tested as antioxidant using DPPH scavenging method. The active fractions were further purified by Column Chromatography. The stationary phase was made up of a glass column packed using Sephadex LH20 with methanol as mobile phase. The chemical composition of the fraction was evaluated using TLC and visualized with UV (254 nm and $366 \mathrm{~nm}$ ). The fractions obtained from the column chromatography results were tested for their antioxidant activity by the DPPH method.

\section{Purification and identification}

The fraction which had the highest activity was purified by TLC preparative $\left(\mathrm{SiO}_{2}\right.$, chloroform-methanol=2:8). Furthermore, the identification by UV-Vis spectrophotometer, Fourier Transforminfrared Spectrometer (FTIR) and GC-MS.

\section{RESULTS AND DISCUSSION}

\section{Phytochemical screening}

The results of the phytochemical screening of andaliman simplicia and extract of n-hexane, ethyl acetate and $70 \%$ ethanol extract contains alkaloids, tannins, flavonoids, saponins, steroids, triterpenoids, essential oils and coumarins. The results can be seen in table 1 .

Table 1: Results of phytochemical screening of andaliman powdered and extracts

\begin{tabular}{llllll}
\hline No. & Group of chemical compound & Powdered & n-hexane extract & Ethyl acetate extract & $\mathbf{7 0 \%}$ ethanol extract \\
\hline 1. & Alkaloids & + & - & + & + \\
2. & Flavonoids & + & - & + & + \\
3. & Saponins & + & - & - & + \\
4. & Tanins & + & - & - & + \\
5. & Quinone & - & - & + & + \\
6. & Steroid/triterpenoids & + + & + & + & + \\
7. & Essential oils & + & + & + \\
8. & coumarins & + & - & + \\
\hline
\end{tabular}

Note: $(+)$ indicates present, $(-)$ indicates absent/not detected

\section{Antioxidant activity test}

The results of antioxidant activity testing of andaliman fruit using nhexane, ethyl acetate and 70\% ethanol) can be seen in table 2. Based on the results of antioxidant activity tests, its shows that $70 \%$ ethanol extract has $\mathrm{IC}_{50}$ value higher than other extracts with $\mathrm{IC}_{50}$ value $84.11 \pm 0.47 \mathrm{ppm}$, which indicates that its activity is strong. 
Vitamin $\mathrm{C}$ as positive control has the highest antioxidant activity that Vitamin $C$ has the power of attenuation against free radicals with $\mathrm{IC}_{50}$ value of $3.37 \mathrm{ppm}$. According to Molyneux (2004), antioxidant activity is very strong when the $\mathrm{IC}_{50}$ is less than $50 \mathrm{ppm}$, strong if the $\mathrm{IC}_{50}$ is $50-100 \mathrm{ppm}$, moderate if the $\mathrm{IC}_{50}$ is $101-150 \mathrm{ppm}$ and weak when the $\mathrm{IC}_{50}$ value is $151-200 \mathrm{ppm}[12]$.

\section{Quality parameters 70\% ethanol extract}

Quality parameters extract consists of specific and non-specific parameters from the extract that used to test is andaliman fruit from the $70 \%$ ethanol extract because of the $70 \%$ ethanol extract as the highest antioxidant activity. Test results can be seen in table 3 and table 4 .

Table 2: Antioxidant activity of andaliman fruits with DPPH free radical scavenging

\begin{tabular}{ll}
\hline Sample & IC $_{\mathbf{5 0}} \mathbf{( p p m )}$ \\
\hline n-hexane extract & $494.85 \pm 1.88$ \\
Ethyl acetate extract & $108.50 \pm 0.08$ \\
$70 \%$ ethanol extract & $84.11 \pm 0.47$ \\
Ascorbic acid & $3.37 \pm 0.02$ \\
\hline
\end{tabular}

Note: The data was written in mean $\pm \mathrm{SD}, \mathrm{n}=3$

Table 3: Specific parameters determination of the $70 \%$ ethanol extract

\begin{tabular}{ll}
\hline Specific parameters & Result \\
\hline Organoleptic & Thick extract \\
Form & brown \\
Color & aromatic odor \\
Smell & Bitter \\
Taste & \\
Measurement of soluble compound content & $70.93 \pm 0.05 \%$ \\
Ethanol soluble compound content & $11.05 \pm 0.04 \%$ \\
Water-soluble compound content & \\
\hline
\end{tabular}

Table 4: Non-specific parameters determination of the $70 \%$ ethanol extract

\begin{tabular}{ll}
\hline Non-specific parameters & Result \\
\hline Loss on drying (\%) & $8.34 \pm 0.1$ \\
Water content (\%) & $2.77 \pm 0.03$ \\
Total ash content (\%) & $3,25 \pm 0.03$ \\
Acid insoluble ash content (\%) & $0.07 \pm 0.01$ \\
Water-soluble ash content (\%) & $11.05 \pm 0.04$ \\
Solvent residual content (\%) & $0.69 \pm 0.01$ \\
Heavy metal contamination & \\
Pb metal contamination (mg/kg) & 0.51 \\
Cd metal contamination (mg/kg) & 0.06 \\
Microbial contamination & \\
Total Plate Number (colony/g) & 340 colony/g \\
Molds and Yeasts Number (colony/g) & 17.71 colony/g \\
\hline
\end{tabular}

Note: The data was written in mean $\pm \mathrm{SD}, \mathrm{n}=3$

Determination of water content is important pharmaceutical preparation, especially extract preparations because the presence of will be a good medium for fungal growth and also a medium for the chemical reaction. The water contains in the extract which the lower water content is more stable to be stored in the long term. From the results, the water content that meet the quality requirement is $<10 \%$.

The results of the determination of residual solvent ethanol with gas-liquid chromatography in the extract obtained $0.69 \%$ ethanol content. The results showed that the residual content still fulfills the requirements of maximum residual solvent in the extract is less than $1 \%$ in accordance with the regulatory of BPOM, 2005. The extract met the requirements to be used as raw material for preparation because contain low ethanol content.

The content of $\mathrm{Pb}$ and $\mathrm{Cd}$ in the extracts can be derived from the environment the plants grow and the production process. The content of heavy metals such as $\mathrm{Pb}$ and $\mathrm{Cd}$ that into the body should be limited in number because it is dangerous for health. Based on the results showed levels of $\mathrm{Pb}$ in the extracts of $0.51 \mathrm{mg} / \mathrm{kg}$ whereas Cd levels of $0.06 \mathrm{mg} / \mathrm{kg}$.

\section{Total flavonoid content}

The principle of determining total flavonoid content using the aluminum chloride method is that is the sample is added $\mathrm{AlCl}_{3}$ will form stable complexes between $\mathrm{AlCl}_{3}$ with carbonyl group at $\mathrm{C}-4$ and hydroxyl group at C-3 or C-5 (flvones/flavonols) so that there is a shift in the wavelength toward visible light which is characterized by the solution producing a more yellow color. The results showed that the $70 \%$ ethanol extract with a band I wavelength of $369.5 \mathrm{~nm}$ dan band II wavelength of $256 \mathrm{~nm}$, so that it can be said the flavonoid group in the $70 \%$ ethanol extract is flavonol. Total flavonoid content of the $70 \%$ ethanol extract was $2.37 \pm 0.02 \%$.

\section{Fractionation, purification and identification}

The results of fractionation using VLC of $70 \%$ ethanol extract showed that the Et-OH.3 fraction had an activity with percent inhibition of $81.73 \%$. The Et-OH.3 fraction was then fractionated by column chromatography using an optimized mobile phase, which is a mixture of chloroform-methanol (8:2), from the results obtained 5 combined fractions. Each fraction from column chromatography was concentrated and tested for its antioxidant activity; obtained fraction Et-OH 3.1 had the highest percent inhibition of $72.88 \%$. The purification results from Et-OH.3 obtained 5 isolates. The isolate EtOH 3.1.1 has the highest activity with percent inhibition of $82.57 \%$ with $\mathrm{IC}_{50}$ value $51.35 \mathrm{ppm}$. The results can be seen in fig. 1-2. The active isolate was identified by UV-Vis, FTIR and GCMS. 


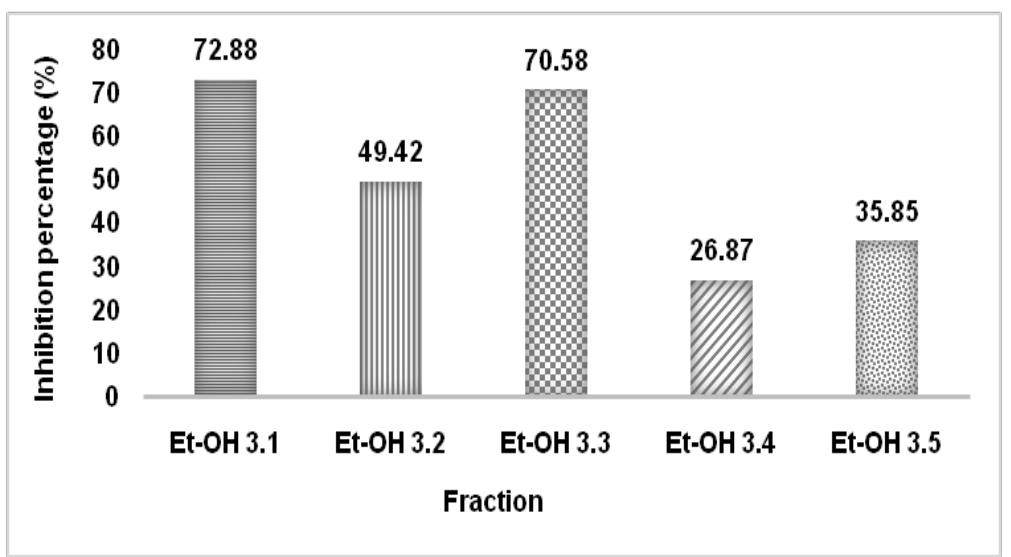

Fig. 2: Antioxidant activity test with DPPH method of fractionation by column chromatography

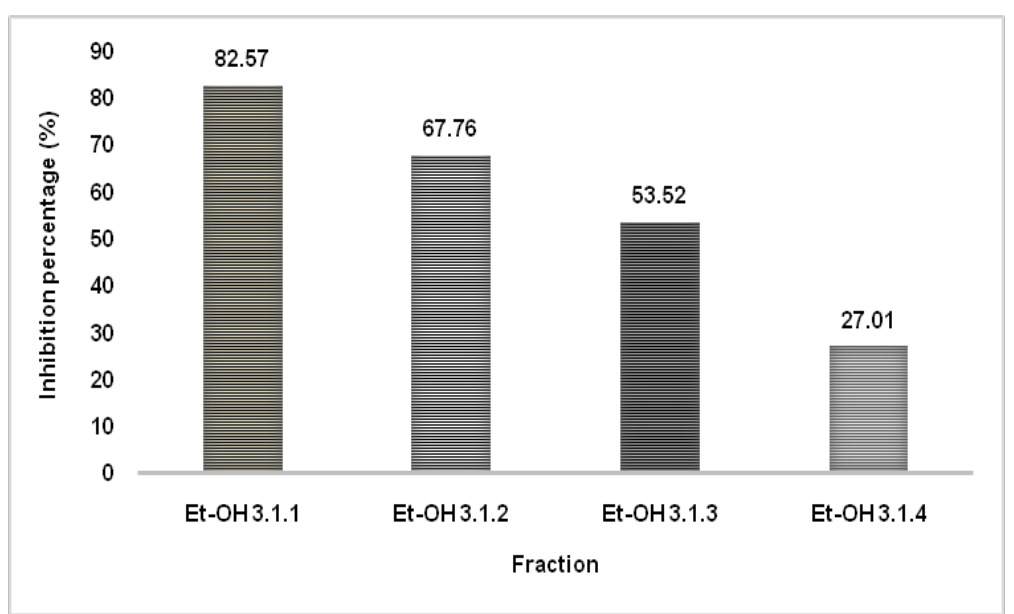

Fig. 3: Antioxidant activity test with DPPH method of fractionation by TLC preparative

The results of the analysis using UV-Vis spectrophotometer against Et-OH.3.1.1 fraction with methanol, obtained the maximum absorption at wavelengths of 223.50 and $269.0 \mathrm{~nm}$.

The results of FTIR spectrum showed that the Et-0H.3.1.1 fraction has- $\mathrm{OH}$ (alcohol, phenol) functional group at $3320.60 \mathrm{~cm}^{-1}$; the presence of hydroxyl is supported by the presence of C-0 at 1114.2 $\mathrm{cm}-1, \mathrm{C}=\mathrm{C}$ at $679.21 \mathrm{~cm}^{-1}$ and $\mathrm{C}-\mathrm{H}$ at $2943.53 ; 1449.22$ and 1411.80 $\mathrm{cm}^{-1}$. The FT-IR spectrum analysis of the Et-OH 3.1.1 fraction can be seen in fig. 3. The interpretation results of GC-MS chromatogram of the Et-OH 3.1.1 fraction can be seen in fig. 4 and table 5 .

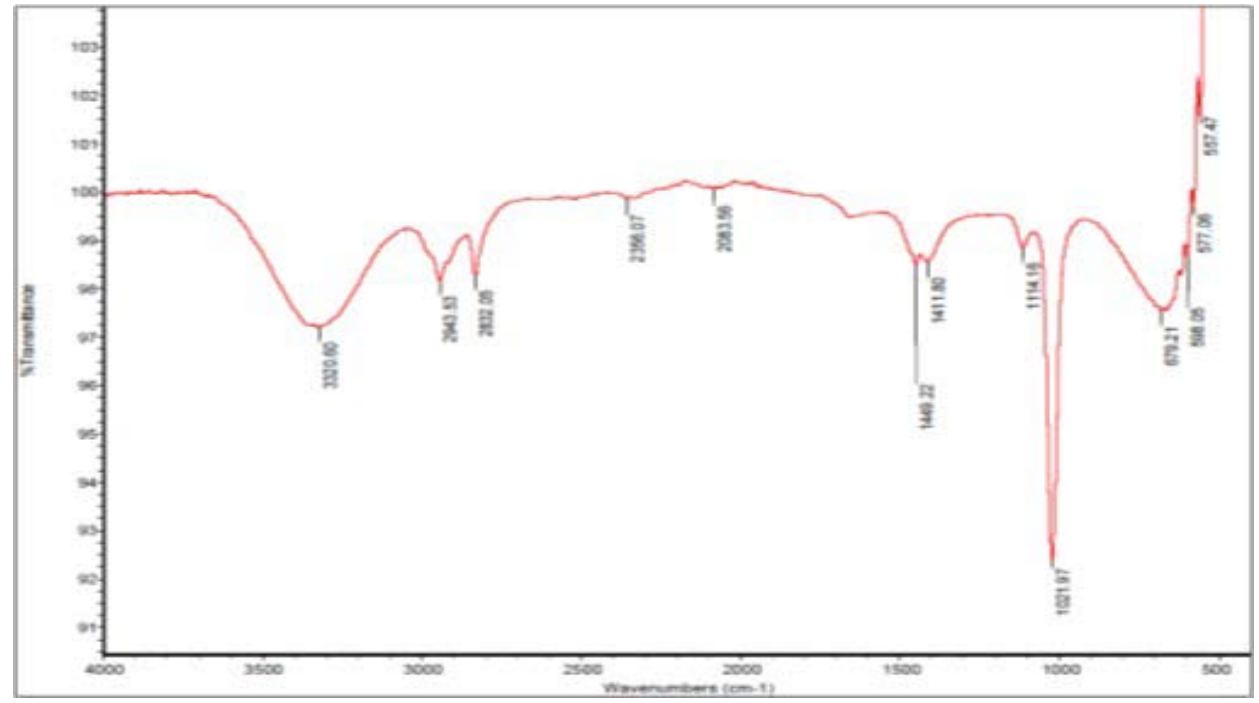

Fig. 3: FT-IR spectrum analysis of the Et-OH 3.1.1 fraction of andaliman fruits extract 


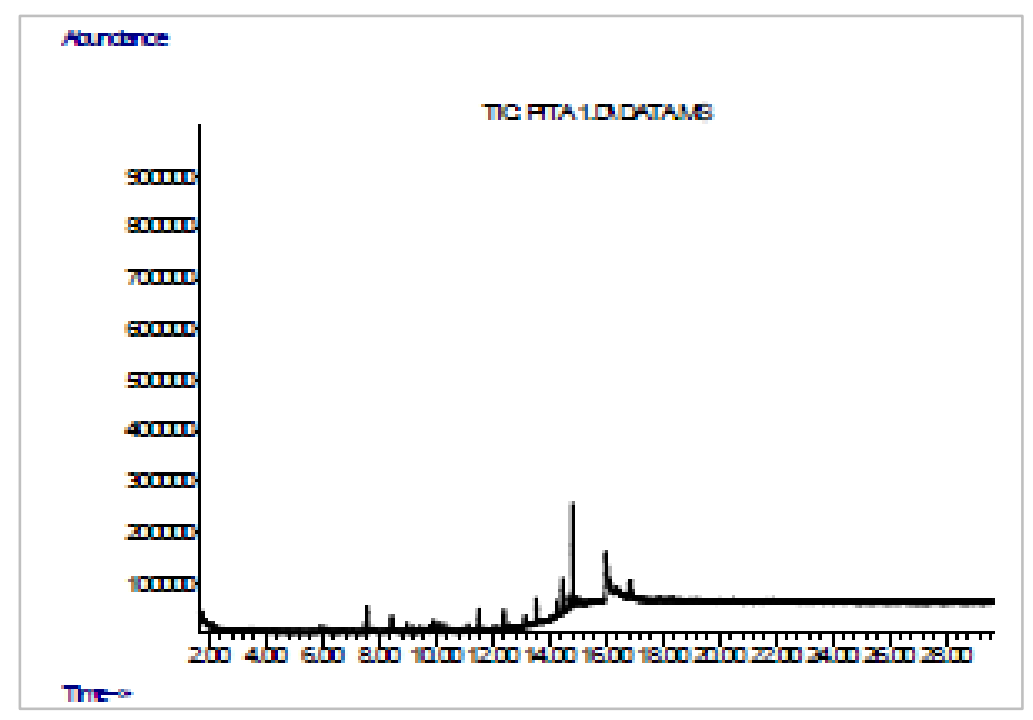

Fig. 4: GC-MS Chromatogram of the Et-OH 3.1.1 fraction of andaliman fruits extract

Table 5: The Interpretation results of GC-MS chromatogram of the Et-OH 3.1.1 fraction of andaliman fruits extract

\begin{tabular}{|c|c|c|c|c|c|}
\hline Peak & IUPAC Name & RT & Area (\%) & MW & Chemical structure \\
\hline 1 & $\begin{array}{l}\text { Pentafluoropropionic acid, dodecyl } \\
\text { ester }\end{array}$ & 7.545 & 1.05 & 332.3 & \\
\hline 2 & 1-Hexadecanol & 7.545 & 1.05 & 242.4 & \\
\hline 3 & Hexadecane & 7.588 & 3.55 & 226.2 & \\
\hline 4 & Methyl palmitate & 9.919 & 1.52 & 270.1 & \\
\hline 5 & Methyl isopalmitate & 9.919 & 1.52 & 270.1 & \\
\hline 6 & $\begin{array}{l}\text { 2-ethylhexyl p- } \\
\text { methoxycinnamate }\end{array}$ & 11.545 & 3.17 & 290.1 & \\
\hline 7 & n-tetracosanol-1 & 13.179 & 2.07 & 355.0 & \\
\hline 8 & $\begin{array}{l}\text { Benzenedicarboxylic acid, } \\
\text { bis (2-ethylhexyl) ester }\end{array}$ & 13.558 & 2.84 & 390.5 & \\
\hline 9 & $\begin{array}{l}\text { 1,2-benzenedicarboxylic acid, mono (2- } \\
\text { ethyl hexyl) ester }\end{array}$ & 13.558 & 2.84 & 279.1 & \\
\hline 10 & 4-isopropyl chalcone & 14.289 & 2.22 & 249.0 & \\
\hline 11 & Squalene & 14.839 & 11.34 & 414.9 & \\
\hline 12 & $\mathrm{~N}, \mathrm{~N}$-Dimethyltryptamine & 16.009 & 25.03 & 188.3 & \\
\hline 13 & Dimenhydrinate & 16.155 & 5.65 & 469.97 & \\
\hline 14 & 2-Methyl-5H-dibenz[b,f]azepine & 16.388 & 4.79 & 207.27 & \\
\hline
\end{tabular}

RT: Retention Time, MW: Molecular Weight 
Based on the results of the GC-MS analysis using the Willey 09th. L database and supported by FTIR data and literature, six estimates of compounds with antioxidant activity were obtained, namely, 1,2benzenedicarboxylic acid, mono (2-ethylhexyl) ester, squalene, methyl palmitate, methyl isopalmitate, n-tetracosanol-1 and 4isopropyl chalcone.

1,2-benzenedicarboxylic acid, mono (2-ethylhexyl) ester is thought to have antioxidant activity because it has- $\mathrm{OH}, \mathrm{C}-\mathrm{O}, \mathrm{C}=\mathrm{C}$ and $\mathrm{C}-\mathrm{H}$ functional groups. According to Krishnan K, et al. (2014) in the FTIR results did not show the presence of $\mathrm{C}=0$ groups can be caused by the resonance of $\mathrm{C}=0$ groups that bind to $\mathrm{C}=\mathrm{C}$, which causes delocalization of electrons, so that $\mathrm{C}=0$ bonds are favored by new bonds and bonds to become weaker [15]. 1,2-benzenedicarboxylic acid, mono (2-ethylhexyl) ester has a similarity percentage of $72 \%$ and an area of $2.84 \%$. In addition, it was supported by the research of Adeyami MA et al. (2017), who stated that 1,2benzenedicarboxylic acid, mono (2-ethylhexyl) ester compounds have antioxidant activity [16]. Squalene is thought to have antioxidant activity due to $\mathrm{C}=\mathrm{C}$ and $\mathrm{C}-\mathrm{H}$ groups. In the $\mathrm{C}=\mathrm{C}$ group, there are $\pi$ and $\sigma$ bonds, where the $\pi$ bond is weaker than the $\sigma$ bond and acts as an electron donor so that it acts as an antioxidant and can make radical compounds become more stable. In addition, supported by the literature Banakar P, et al. (2018), squalene has antioxidant activity. Squalene compounds contained in isolates have $99 \%$ similarity and area of $11.34 \%$ [17].

Methyl palmitate and methyl isopalmitate are thought to have antioxidant activity because in both compounds, there are $\mathrm{C}-\mathrm{H}$ and $\mathrm{C}-\mathrm{O}$ groups. The antioxidant activity is thought to originate from the methoxy groups found in methyl palmitate and methyl isopalmitate. Also supported by the literature Zayed et al. (2014) [18] and Elizabeth et al. (2014), which states that the compound has antioxidant activity. The methyl palmitate compound contained in the isolate had $97 \%$ similarity and an area of $1.52 \%$, while methyl isopalmitate had $96 \%$ similarity and an area of $1.52 \%$ [19].

n-tetracosanol-1 is thought to have antioxidant activity because there are $\mathrm{C}-\mathrm{H}$ and- $\mathrm{OH}$ groups. The n-tetracosanol- 1 compound is a primary alcoholic group that can undergo oxidation to aldehydes or carboxylic acids, so it is thought to be an antioxidant. Also supported by the literature Amudha et al. (2018) which states that the compound n-tetrachosanol-1 has antioxidant activity [20]. The ntetracosanol-1 compound contained in the isolate had a similarity percentage of $78 \%$ and an area of $2.07 \%$. 4-isopropyl chalcon is thought to have antioxidant activity.

The n-tetracosanol-1 compound contained in the isolate had a similarity percentage of $78 \%$ and an area of $2.07 \%$. 4-isopropyl chalcon is thought to have antioxidant activity because there are $\mathrm{C}-\mathrm{H}$ and $C=C$ groups in this compound. The FTIR results did not show the presence of $\mathrm{C}=0$ groups can be due to the resonance effect that causes the $\mathrm{C}=\mathrm{O}$ bond is like a single bond. Also supported by the literature Ohkatsu et al. (2008) which states that chalcone compounds are intermediates for flavonoid biosynthesis, which have antioxidant activity [21]. The 4-isopropyl chalcon contained in the isolate had a similarity of $43 \%$ and an area of $2.22 \%$.

Based on the research of Moelyono et al. (2014) showed the presence of several chemical compounds found in fruit andaliman such as $\alpha$ terpineol, Linalool oxide, linalool, citronella, limonene oxide, $\beta$ citronellol, nerol, geraniol, hydroxyl-linalool, nerolidol, 1-naptalenol, farnesol, and farnesol acetate [9]. Based on the results of research conducted on Et-OH 3.1.1 fraction, there are compounds with an $\mathrm{m} / \mathrm{z}$ value of 226.2 that has similarities with fernesol and nerolidol, which have $\mathrm{m} / \mathrm{z}$ 222.27. Differences in molecular weights can be caused by oxidized double bonds. Although the results obtained, have different molecular weights, but based on the chemical structure in accordance the results of an analysis of UV-Vis spectrophotometry, FT-IR, GC-MS and also supported by literatures that shows the antioxidant activity of these compounds, the possibility of mono compounds (2-ethylhexyl) 1,2benzendikarboxylate, squalen, methyl palmitate, methyl isopalmitate, $n$ tetracosanol-1 and 4-isopropyl chalcon still contain antioxidants from isolates 3.1.1 ethanol extract of $70 \%$ andaliman fruits.

\section{CONCLUSION}

The Andaliman fruit The 70\% ethanol extract of andaliman fruits
(Zanthoxylum acanthopodium DC.) had higher antioxidant activity (IC 50 84.11 \pm 0.47 ppm) compared to $n$-hexane extract (IC 50 $494.85 \pm 1.88 \mathrm{ppm}$ ) and ethyl acetate extract ( $\left.\mathrm{IC}_{50} 108.50 \pm \mathrm{ppm}\right)$ and Total flavonoid levels of the $70 \%$ ethanol were $2.37 \pm 0.03 \%$. The quality parameters of the $70 \%$ ethanol extract of the andaliman fruit met the requirements of the terms extract as a raw material preparation of traditional medicine. Based on the results of identification by UV-Vis spectrophotomety, FT-IR, and GC-MS, it is suspected that the compounds which have antioxidant activity in Et$\mathrm{OH}$ isolates, namely mono (2-ethylhexyl) 1,2-benzendicarboxylic; squalene; methyl palmitate; methyl isopalmitate; n-tetracosanol-1 and 4-isopropyl chalcone.

\section{ACKNOWLEDGMENT}

The author gratefully acknowledges to thank the Q-lab and Research Laboratory Faculty of Pharmacy University of Pancasila who have provide facilities for this research.

\section{FUNDING}

Nil

\section{AUTHORS CONTRIBUTIONS}

All the authors have contributed equally.

\section{CONFLICT OF INTERESTS}

No conflicts of interest with respect to the research, authorship, and/or publication of this article.

\section{REFERENCES}

1. Pietta PG. Flavonoid and antioxidant. J Nat Prod 2000;63:103542.

2. Saxena M, Saxena J, Pradhan A. Flavonoids and phenolic acids as antioxidants in plants and human health. Int J Pharm Sci Rev Res 2012;16:130-4.

3. Kristanty RE, Suriawati J. The Indonesian Zanthoxylum acanthopodium DC. chemical and biological values. Int J Pharm Tech Res 2015;8:313-21.

4. Heddy Julistiono, Fani Gustiani L, Rifki Iryanto, Puspa Dewi L. Antimycobacterial activity of fruit of Zanthoxylum acanthopodium DC against mycobacterium smegmatis. Avicenna J Phytomed 2018;8:432-8.

5. Tensiska, Wijaya CH, Andarwulan N. Antioxidative activity of andaliman fruit extract (Z. acanthopodium DC.) on several food system and its antioxidative stability on temperature and $\mathrm{pH}$ influence. J Teknologi Dan Industri Pangan 2003;14:31-2.

6. Banjamahor S, Artanti N. Antioxidant properties of flavonoids. Med J Indonesia 2014;23:239-44.

7. Reginold Jebitta S, Jeyanth Allwin S. Antioxidant activity, total phenol, flavonoid and anthocyanin contents of jamun (Syzigium cumini) pulp powder. Asian J Pharm Clin Res 2016;9:361-3.

8. Kristanti RE, Munim A, Katrin. Antioxidant activity and xanthine oxidase inhibitor from andaliman fruit (Zanthoxylum acanthopodium DC). Pharm J Indonesia 2013;6:1-5.

9. Moektiwardoyo M, Muchtaridi Muchtaridi, Eli Halimah. Chemical composition and locomotor activity of Andaliman fruits (Zanthoxylum acanthopodium DC) essential oil on mice. Int J Pharm Pharm Sci 2014;6:547-50.

10. Farnsworth NR. Biological and phytochemical screening of plants. J Pharm Sci 1966;55:225-76.

11. Harborne JB. Phytochemical methods. A guide to modern techniques of plant analysis. $2^{\text {nd }}$ ed. London: Chapman and Hall; 1984.

12. Molyneux P. The use of the stable free radical diphenylpicrylhydrazyl (DPPH) for estimating antioxidant activity. Songklanakarin J Sci Technol 2004;26:211-9.

13. Blois MS. Antioxidant determination by the use of a stable free radical. Nature 1958;26:1199-200.

14. Department of Health. Parameter standar umum ekstrak tumbuhan obat. DitJen POM, Direktorat Pengawasan Obat Tradisional; 2000. p. 13-37.

15. Krishnan K, Mani A, Jasmine S. Cytotoxic activity of bioactive compound 1,2-benzene dicarboxylic acid, mono 2-ethylhexyl 
ester extracted from a marine-derived Streptomyces $s p$. VITSJK8 2014;3:246-54.

16. Adeyami MA, Ekunseitan DA, Abiola SS, Dipeolu MA, Egbeyale LT, Sogunle OM. Phytochemical analysis and GC-MS determination of Lagenaria breviflora R. fruit. Int J Pharmacogn Phytochem 2017;9:1048.

17. Banakar P, Jayaraj M. GC-MS analysis of bioactive compounds from ethanolic leaf extract of Waltheria indica linn. and their pharmacological activities. Int J Pharm Sci Res 2018;9:2005-10.

18. Zayed MZ, Ahmad FB, Ho WS, Pang SL. GC-MS analysis of phytochemical constituent in leaf extracts of Neolamarckia cadabma (Rubiaceae) from Malaysia. Int J Pharm Sci Res 2014;6:123-7.

19. Elizabeth V, Arumugam S. GC-MS analysis of bioactive constituent of Indigofera suffruticosa leaves. J Chem Pharm Res 2014;6:292-300.

20. Amudha P, Jayalakshmi M, Pushpabharati N, Vanitha V. Identification of bioactive component in enhalus acoroides seagrass extract by gas chromatography-mass spectrometry. Asian J Pharm Clin Res 2018;11:313-7.

21. Ohkatsu Y, Satoh T. Antioxidant and photo-antioxidant activities of chalcone derivatives. J Japan Petroleum Institute 2008;51:298-307. 